\title{
Open access and liberal arts colleges Looking beyond research institutions
}

Editor's note: Readers of this column are familiar with the development of open access policies and their implementation at research universities. But what about liberal arts colleges? In this issue's column, Jonathan Miller explains how a faculty open access policy is both a critical element of information services and an extension of his college's mission.

S ince the Arts and Sciences faculty of Rollins College passed their open access (OA) Policy in February 2010, a number of colleagues from around the country have expressed surprise that Rollins should be one of the first liberal arts college faculties to pass such a policy. In fact, we were third, after Trinity University in San Antonio and Oberlin College in Oberlin, Ohio, and we should not forget colleges like Gustavus Adolphus in Saint Peter, Minnesota, at which the library faculty as a department passed a policy in support of open access.

The Rollins policy is modeled on the example set by Harvard and others.

Each member of the faculty of Arts \& Sciences grants to Rollins College nonexclusive permission to make available the final, peer-reviewed, manuscript version accepted for publication of his or her scholarly articles ... and to exercise all rights under United States copyright law in those works for the purpose of open dissemination. ... The policy will apply to all peer-reviewed scholarly works, including works jointly authored with persons who are not members of the Rollins faculty of Arts \& Sciences, written while the person is a member of the faculty except for any works completed before the adoption of this policy, any works for which the faculty member entered into an incompatible licensing or assignment agreement before the adoption of this policy, and any work for which the author might reasonably expect to receive royalties (including monographs, textbooks, musical, or other creative works.). The Professional Standards Committee will waive application of the policy for a particular work upon written notification by the author, who informs Professional Standards Committee of the reason.

Colleagues are surprised because they assume OA is an issue for researchers and the large universities that employ the majority of them. I argue that OA is not just the concern of research universities. In fact, it might be even more relevant for smaller colleges than for larger schools.

Rollins is a largely undergraduate, teaching intensive school with a liberal arts curriculum. This means that, at least in one sense, we need broad not deep access to information. We are net information consumers, rather than net producers. The subscription model of collecting a relatively small number of periodical titles "just in case," doesn't make

Jonathan Miller is director of Olin Library at Rollins College, e-mail: jxmiller@rollins.edu

Contact Mike Furlough — series editor, assistant dean for scholarly communications, and codirector of the Office of Digital Scholarly Publishing at Penn State Universitywith article ideas, e-mail: mfurlough@psu.edu

() 2011 Jonathan Miller 
much business sense for a school like us. What we really need is "just in time" access to a broad array of information resources, none of which will be used particularly heavily.

Our OA policy is one part of a larger strategy to refocus the faculty and students on a larger world of information and not solely a local library collection. With the enthusiastic support of many faculty, we have repositioned the library as one (we hope important) node in an information network that requires ever closer cooperation and collaboration with other libraries and information providers and which includes local print and digital collections, licensed access to a lot more, and open access to even more scholarly and nonscholarly information. In this model the librarians are the faculty and students' guides and partners in a larger, richer, but more complicated information environment. Placing OA within this multi-part strategy means that the librarians are seen as trusted partners in developing a faculty OA policy.

There are three parts to this strategy that are relevant here:

1. Working politically to create the scholarly communication system we prefer and that meets the needs of the students and faculty at liberal arts colleges.

2. Moving aggressively from print to digital periodicals.

3. Contributing to OA initiatives and exploiting OA resources.

\section{Working politically}

In 2009, I led an effort among liberal arts college library directors to protest the Nature Publishing Group's exorbitant increase in the online subscription price for Scientific American. We also cancelled our print subscription. This was not universally popular on campus because some faculty used articles from the magazine to initiate class discussion, but it was an opportunity to explain why we thought we had to hold the line on periodical prices and why OA might help. I have also served on the ACRL Government Relations Committee and the SPARC Steering Committee. Both play leading roles in advo- cating for OA. My own research concerns the history of copyright policy and libraries, and I have looked for opportunities to present that research to my colleagues and have built a reputation as someone with whom they can discuss scholarly communication and copyright issues.

\section{Aggressively moving from print to digital periodicals}

Obviously, most, if not all, academic libraries are migrating from print to digital periodicals. At Rollins we are doing so for common reasons that include user preference, space, and the ability to link articles to wider information systems, thus making them more accessible to our users. But, in response to flat collections budgets over the last few years, we also did a major print periodical cancellation project in 2008-09. We focused on print subscriptions because low use and increases in subscription prices have become unsustainable.

Working closely with faculty on this project increased their awareness of just how expensive the annual subscriptions to scholarly periodicals have become. The project was about cuts, but we described it as a necessary pruning. We made sure that faculty understood that if and when budgets improved, we would consider adding subscriptions to digital content. In the meantime, we continued to make them aware of OA journals and repositories and made sure to incorporate these open resources, through the Serials Solutions knowledgebase and the work of our liaison librarians, into our systems and services.

\section{Exploiting resources and contributing to initiatives}

If we encourage our faculty and students to use OA resources as information consumers, shouldn't we also contribute to those resources as information producers? This question is particularly important to those of us who work in liberal arts colleges. The liberal arts originally meant the education appropriate for free men (from the Latin liber, free). Liberal arts colleges in the United States 
have built on this foundation a program of study designed to educate informed citizens and full participants in a democratic society. Rollins' mission is to educate students as global citizens and responsible leaders, and we have a national reputation for community engagement. It is unthinkable that Rollins faculty, and by extension their students, would take advantage of open access to materials produced at the expense of others without also promoting open access to scholarly information that they create.

\section{Rollins's OA policy}

Before we began working on the policy, we were given good advice by those who had traveled this road before us. So I pass this on to you:

- Find faculty champions for your $O A$ policy. As a librarian, this should be your primary task. Once you have identified your faculty champions, then you can play a role in the background, providing information, answering questions, reassuring faculty that administering the repository is a role the library can perform. Most successful OA policy initiatives have been faculty initiatives.

The faculty champions on our campus were both members of the Professional Standards Committee: Thom Moore, a physicist who directs the faculty/student collaborative research program, and Claire Strom, a historian and journal editor of Agricultural History. Strom drafted the policy, Moore shepherded it through the faculty. Both are active researchers and well respected on campus and beyond.

- Develop the policy and the institutional repository simultaneously. This can be expensive in either time or money and could result in a successful implementation of the repository, but no policy. However, that is not necessarily a bad thing. Many colleges and universities have successful repositories of many kinds of materials, including faculty publications, without a formal OA policy. Building the repository at the same time as you press for the policy means that faculty will be able to see practical examples of how their works will be archived and accessed. This can reassure faculty in disciplines that are not already making extensive use of disciplinary repositories or who have a difficult time envisaging a transformed system of scholarly communication in which bound journals on the library shelves do not play a primary role.

- Find the message that resonates with particular audiences on your campus. At Rollins, faculty were interested in a more open system with more visibility for their own research and wanted a policy that recognized the diversity of their work and was flexible enough to enable them to get an automatic waiver when necessary (fully half of the publishing output of Rollins faculty is something other than the classic peer-reviewed scholarly article, such as books, textbooks, creative works, or nonscholarly professional or applied publications.) The provost was interested in institutional reputation and the dean of faculty was interested in the idea of a stable repository of faculty publications.

The policy passed the Arts and Sciences faculty unanimously in February 2010. The institutional repository site, Rollins Scholarship Online (scholarship.rollins.edu), went live at the same time. We spent the first half of 2010 tweaking the site and loading materials. In fall 2010, we received the data on last year's publications, drawn from the annual reports each faculty member submits to the dean. David Noe, who administers the institutional repository, asked each faculty member to submit their publications that meet the criteria of the policy. He also assists them with submission or the waiver, where necessary.

\section{Next steps}

Once the policy has passed and the repository is up and running, your work has really only just begun. The tasks before us at Rollins include the following.

- Continuing to populate the repository. A few faculty members have chosen to selfsubmit but most have not. The reasons why faculty authors submit, or not, to institutional repositories could be the subject of another column. 
- Passing a similar policy with the other faculty on campus. Rollins has two faculties, the Arts and Sciences faculty of the liberal arts college and the faculty of the Crummer Business School. So far, our early discussions have been very positive and we expect that faculty will look favorably on a similar policy.

- Reaching out to journal editors on campus - both faculty and students-and offering to host their content. Like most colleges, Rollins is home to a number of journal editors. Some are formal, scholarly society efforts, like Agricultural History. Others are home-grown products of the entrepreneurial spirit within the faculty, and still others are student publications. Our institutional repository can manage online journals, both open and toll access. So we are approaching the decision makers associated with each journal to determine whether they would like the online iteration of their journal to be hosted at Rollins Scholarship Online. This is also an opportunity to discuss the wider issues of OA with people who can have an impact on scholarly publishing on a wider scale than that of individual authors.

- Building other collections into the repository. With a small faculty, an institutional repository that only included faculty publications would be very small. But we can consider other collections. Wenxian Zhang, our special collections librarian and archivist, has proposed creating a repository of theses, which to this date have been housed in bound volumes in our archives. An investment group, managed by students in the Crummer Graduate School of Business, is interested in archiving their annual reports online and, in what we hope is the first of many such opportunities, a history professor has approached us to discuss how we might archive student-authored multimedia class projects.

We continue to work on other elements of our strategy to move the focus of the faculty and students of Rollins College on a larger information environment. The long-term (continues on page 30)

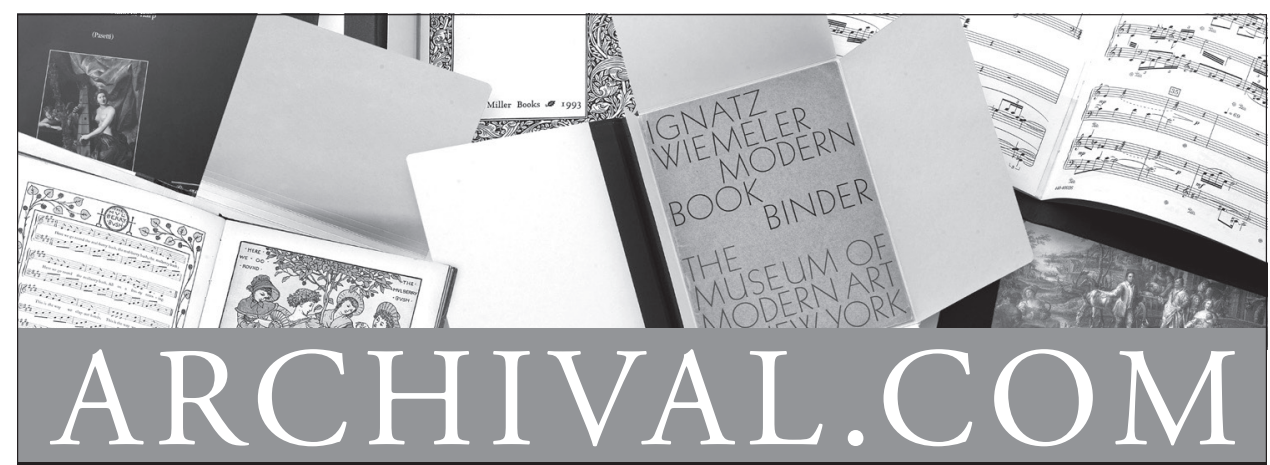

INNOVATIVE SOLUTIONS FOR PRESERVATION

Call for a complete catalog

Pamphlet Binders Music Binders Archival Folders Manuscript Folders Hinge Board Covers Academy Folders Newspaper/Map Folders Bound Four Flap Enclosures Archival Binders
Polypropylene Sheet \& Photo Protectors Archival Boards Adhesives Bookkeeper Century Boxes Conservation Cloths Non-Glare Polypropylene Book Covers CoLibri Book Cover System

\section{ARCHIVAL PRODUCTS}

P.O. Box 1413

Des Moines, Iowa 50306-1413

Phone: 800.526.5640

Fax: 888.220.2397

E-mail: custserv@archival.com Web: archival.com 
or their profile. Students might say, "I don't want my parents to know what I'm up to" or "I don't want someone to judge me for what I say or what pictures I have." You might infer that some students value their privacy and explain that libraries value all patrons' privacy and discuss the reasons why. It's a great way to start the conversation and allow students to participate in discussion on this issue.

- Library interfaces change just like the Facebook interface changes. Students often complain about how "complicated" library catalogs and library databases are, and how frustrated they get when an interface changes. If this comes up in a session you might talk about the fact that the Facebook interface also changes frequently, and while each student contributes content to the Facebook "database," the student themselves does not have control over the Facebook interface. This is the same as most library catalogs and library databases. It is usually the vendor that is responsible for the changes, and it is usually based on feedback from users.

Letting them know we realize that it is frustrating goes a long way and helps students understand that the library itself is not necessarily responsible for changes in subscription-based products.

- As a Facebook user, you are constantly evaluating information. You might ask students what they do when they encounter a friend's status update that relates to an item in the news. "When you see a friend's status update about a newsworthy event, what do you do?" Students will usually say that they click on a link if it's provided or they Google the headline. You might ask them why they don't just take their friend's word that the story is true. Having a discussion about why they feel the need to get more information and how that relates to their own research can be helpful in reinforcing the idea of information evaluation. A discussion about obtaining multiple sources of information and evaluating authority and currency should ensue.

Using Facebook as a starting point in library instruction has had a tremendous impact on my teaching. There are other concepts that I've related to Facebook, as well: "browsing versus searching," "information overload," "the complexity of information," "information growth," and others. I find students are interested in the session and they seem to grasp the concepts I'm discussing more firmly. It makes library instruction relevant and fun, and it has transformed my teaching style. I have moved from lecturing to a discussion-based approach, and I find that this has improved the outcome of my instruction sessions. These same concepts are just as applicable when answering questions at the reference desk. While we may not completely relate to students, we can at least try to help them relate to the concepts that they will need to understand to be information literate, and perhaps Facebook just might be one way to do that. $\boldsymbol{n}$

("Open access..." continued from page 19)

work of collaborating and cooperating with other libraries in Florida continues, as does the similarly long-term migration from print to digital resources. We also continue in our political work in our efforts to persuade Congress that passing the Federal Research Public Access Act (FRPAA, H.R. 5037) is good public policy that will improve access to federally funded research for researchers, consumers, and the students and faculty of liberal arts colleges. At least now Rollins can say we are putting our money where our mouth is.

\section{Note}

1. The College's OA Policy and institutional repository would not have come to fruition without the sustained effort of many people, including Thomas Moore, Archibald Granville Bush professor of science and professor of physics; Claire Strom, RapettiTrunzo chair of history; Bill Svitavsky, head of digital services and systems; David Noe, digital services librarian; Peter Suber, senior researcher at SPARC; and Jonathan Cadle, Berkeley Electronic Press. n 